and if further the placental discrimination is 0.62 as found by Bryant and Loutit, then the serum calcium of the mother can be expected to be $0.62 / 0.82$ or 76 per cent that of the new-born. This increased concentration of calcium in tho infant's serum as compared with that of the mother is consistent with Comar's findings in animal experiments ${ }^{4}$, but requires verification in examination of human beings.

I thank Dr. Arthur Weinberg for obtaining the blood samples for this work.

JOSEPH RIVERA

U.S. Atomic Energy Commission,

Health and Safety Laboratory, Now York, New York. ' Wasserman, R. H., Comar, C. L., Nold, M. M., and Lengemann, F. W.
Amer. J. Physiol., 189, 1 (1957).

${ }^{2}$ Bryant, F. J., and Loutit, J. F., Rep. No. AERE-R 3718 (London, 1961).

${ }^{3}$ Dixon, W. J., Ann. Math. Stat., 22, 68 (1951).

4 Comar, C. L., Ann. N.Y. Acad. Sci., 64, 281 (1956).

\section{Influence on Capillary Permeability of Lymph discharged from a Scald}

Atrention has recently been directed to the protein permeability factor while investigating the pathogenesis of disturbance of the capillary permeability ${ }^{1-4}$.

Investigations were carried out to determine the properties of lymph discharged from a scald. The lymph was collected from the popliteal nodes of rabbits $(2 \cdot 0-3 \cdot 0 \mathrm{~kg})$ and proteins were separated by paper electrophoresis (veronal buffer, $\mu 0 \cdot 023, p H ~ 8.6$ ). The influence of lymph on capillary permeability was investigated by introducing the lymph $(0.1 \mathrm{ml}$.) intracutaneously into a rabbit previously injected intravenously with $T-1824$ or trypan blue $(10 \mathrm{mg} / \mathrm{kg})$. The scald was caused by dipping the hind-leg into water of $80 \pm 2^{\circ} \mathrm{C}$ for $1 \mathrm{~min}$, and $50 \pm 0.5^{\circ} \mathrm{C}$ for $5 \mathrm{~min}$.

In the lymph collected from 15 rabbits, $30 \mathrm{~min}$ and $24 \mathrm{~h}$ after the burn at $80^{\circ} \mathrm{C}$ (Table 1 ) protein concentration increased, the $A / G$ coefficient decreased and $\beta$-globulin concentration increased $(P<0.001)$. In lymph obtained $24 \mathrm{~h}$ and, in several cases, $30 \mathrm{~min}$ after the burn, an additional globulin fraction was registered, located between $\beta$ - and $\gamma$-globulin ( $\beta_{2}$-globulin).

Results from scalds made at a lower temperature $\left(50^{\circ} \mathrm{C}\right)$ with 10 rabbits were somewhat different. The protein concentration in the lymph increased $(P<0.001)$, but the $A / G$ coefficient did not decrease; $\beta$-globulin concentration did not increase, nor was any additional $\beta$-globulin fraction discovered. At $50^{\circ} \mathrm{C}$ the actual swelling appeared after $2 \cdot 0-2.5 \mathrm{~h}$ and continued increasing during $24 \mathrm{~h}$. In contrast to the experiments at $80^{\circ} \mathrm{C}$ no destructive changes were noted in scalded paws.

The lymph obtained $24 \mathrm{~h}$ after scalding at $80^{\circ} \mathrm{C}$ in all cases caused acute disturbances in the capillary permeability. The influence of the lymph obtained $30 \mathrm{~min}$ after the scald was weaker. Lymph collected $24 \mathrm{~h}$ after scalding at $50^{\circ} \mathrm{C}$ did not provoke permeability derangement, while that obtained $30 \mathrm{~min}$ after scalding was active only in 7 out of 15 experiments.

Antihistamines ('Dimedrol', 'Alphadril') practically eliminated the influence of the capillary permeability of lymph collected $30 \mathrm{~min}$ after scalding at $50^{\circ}$ and $80^{\circ} \mathrm{C}$, and there was a slight weakening of the influence of the lymph obtained $24 \mathrm{~h}$ after scalding at $80^{\circ} \mathrm{C}$. This might be explained by the participation of histamine in the

Table 1. Elhctrophoretuc ANALYSIS OF LYMPH

\begin{tabular}{|c|c|c|c|c|c|c|c|c|}
\hline \multirow[b]{2}{*}{ Before } & $\underset{(\%)}{\text { Albumin }}$ & \multicolumn{5}{|c|}{ Globulins (\%) } & $\begin{array}{c}A / G \\
\text { coeff. }\end{array}$ & $\begin{array}{c}\text { Protein } \\
(\mathrm{g} / \%)\end{array}$ \\
\hline & & & & & & & & \\
\hline & $50 \cdot 2$ & 6.9 & $12 \cdot 9$ & $14 \cdot 0$ & - & $16 \cdot 0$ & 1.03 & $3 \cdot 2$ \\
\hline $30 \min$ & $45 \cdot 7$ & $7 \cdot 0$ & $11 \cdot 1$ & 11.5 & $7 \cdot 7$ & $17 \cdot 0$ & 0.87 & $3 \cdot 4$ \\
\hline $24 \mathrm{~h}^{P}$ & $<0.001$ & $<0.5$ & $<0.1$ & 100 & & $<0.5$ & $<0.001$ & $<0.01$ \\
\hline & $\begin{array}{l}43.2 \\
<0.001\end{array}$ & $\begin{array}{r}7.3 \\
<0.5\end{array}$ & $\begin{array}{r}11 \cdot 2 \\
<0.5\end{array}$ & $10 \cdot 0$ & $10 \cdot 7$ & $\begin{array}{r}17.8 \\
<0.5\end{array}$ & $\begin{aligned} & 0.78 \\
< & 0.001\end{aligned}$ & $\begin{array}{r}3.8 \\
<0.001\end{array}$ \\
\hline
\end{tabular}

first phases of the inflammation and the subsequent inclusion of active globulins $\mathrm{s}^{5,6}$.

The appearance of unusual $\beta$-globulins in the rabbit's lymph during scalding coincides with previous investigations made in our laboratory ${ }^{7}$. It seems that during inflammation not only are the existing globulin permeability factors activated but also unusual globulins are formed ${ }^{8}$.

In spite of intensive swelling at the site of the scald at $50^{\circ} \mathrm{C}$, the lymph after $24 \mathrm{~h}$ did not cause capillary permeability disturbances and did not contain histamine and globulins with unusual electrophoretic mobility. It is possible that under the influence of moderate tem. peratures the mediators causing capillary permeability derangement in rabbits, just as in rats, are other factors affecting permeability ${ }^{9,10}$.

\section{A. Oyvin \\ S. M. SHegel \\ E. G. YAGODKINA}

Department of Pathological Physiology, Kuban Medical Institute, Krasnodar, U.S.S.R.

${ }^{1}$ Miles, A. A., and Wilhelm, D. L., Brit. J. Exp. Path., 36, 71 (1955).

${ }^{2}$ Paskhina, T. s., Clin. chim. Acta, 1, 24 (1956).

${ }^{3}$ Spector, W. G., and Willoughby, D. A., Nature, 182, 949 (1958).

-Wilhelm, D. L., Mill, P. I., Sparrow, W. E., Mackay, M., and Milles, A. A. Brit. J. Exp. Path., 39, 228 (1958).

${ }^{5}$ Spector, W. G., J. Path. and Bact., 72, 367 (1956).

- Wilhelm, D. L., and Mason, B., Brit. J. Exp. Path., 41 (5), 487 (1960).

'Bakanskaya, V. V., Bull. Exp. Biol. Med., 45 (5), 36 (1958).

Troizky, G. V., Okulov, V. I., and Sorkina, D. A., Biokhimiya, 26 (1), 44 (1961).

Rocha-e-Silva, M., and Antonio, A., Med. Exp., 3 (6), 371 (1960).

10 Lewis, G. M., New Sci., 16, 34 (1962).

\section{PHARMACOLOGY}

\section{Quaternized Sympathomimetic Amines}

IN their paper on sympathomimetic amines, Barger and Dale ${ }^{1}$ described the action of hordenine (the $N: N$ dimethyl derivative of tyramine), and showed that the quaternary derivative, hordenine methiodide $\left(1 ; R^{\prime}=\right.$ $R^{\prime \prime}=\mathrm{H}$ ), had a nicotine-like action.

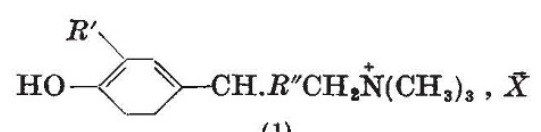

(1)

( $\bar{X}=$ chloride, bromide or iodide $)$

They also found that the trimethylammonium derivative ( $1 ; R^{\prime}=\mathrm{OH}, R^{\prime \prime}=\mathrm{H}$ ) of dopamine had a stronger nicotinelike action, about as strong as nicotine itself.

These compounds, together with the trimethylammonium derivative $\left(1 ; R^{\prime}=R^{\prime \prime}=\mathrm{OH}\right)$ of noradrenaline, have recently been made again by our colleague, Dr. A. M. Creighton, and have been compared, with nicotine on the blood pressure of a spinal cat, and on other preparations. The full results will be described in detail elsewhere. Calculations were made in terms of active base. The general statement can be made that: (1) hordenine methiodide was found to be approximately equal to nicotine in pressor action; (2) the quaternary derivative of dopamine was about four times as active as nicotine; (3) the corresponding derivative of noradrenaline possessed only one-tenth of the action of nicotine. Thus the nicotine-like action was greatly reduced when $R^{\prime \prime}=\mathrm{OH}$.

These results led us to compare the pressor effects of ethyltrimethylammonium bromide with that of choline chloride. Both compounds have a pressor action in the spinal cat which is abolished by hexamethonium. Ethyltrimethylammonium was found to be about 40 times more active than choline expressed in terms of active base. Thus in this pair of compounds, also, the presence of an 